A Note on Expanding the Unit of Analysis from Firms to Supply Networks

Trond Hammervoll

Professor

Harstad University College

trond.hammervoll@hih.no 


\title{
A Note on Expanding the Unit of Analysis from Firms to Supply Networks
}

\author{
Abstract \\ Purpose: There is strong interest in new supply chain management (SCM) constructs as \\ contemporary academic writers call for more theory and more multidisciplinary research. \\ There is, however, little guidance on how to develop relevant SCM-constructs, and one \\ problem is that current SCM-research addresses different units of analysis, ranging from \\ transactions to entire supply networks. The choice of unit of analysis has implications for \\ the relevance of SCM-research, and the purpose of this paper is to increase researchers and \\ practitioners' awareness of this issue.
}

Approach: Conceptual analysis of current SCM-research with special emphasis on SCMconstructs, their variability assumptions, and the explanatory purpose of research.

Findings: Suggestions on how to develop appropriate SCM-constructs at the supply network level. Propositions apt at guiding further study are suggested.

Implications: In order to improve the relevance of SCM-research it is time for studying supply network characteristics, and this requires developing new constructs taking the supply network as the unit of analysis. In practise, one opportunity for SCM-research is to develop new constructs or adopt constructs from related fields taking firm networks as the unit of analysis, and collect data on supply network characteristics from key-informants.

Originality/value of paper: This paper addresses two gaps in the SCM-literature; 1) the failure to consider the entire supply network as the unit of analysis, and 2) the lack of guidance in SCM-literature on how to expand the unit of analysis from one firm to the entire supply network.

Key words: Unit of analysis, supply networks, supply chain management

\section{Conceptual paper}




\section{INTRODUCTION}

Oliver and Webber (1982) introduced the concept of supply chain management (SCM) stressing in particular that 'it views the supply chain as a single entity rather than relegating fragmented responsibility for various segments in the supply chain to functional areas such as purchasing, manufacturing, distributions and sales...' (Oliver and Webber, 1982, p. 66). The Council of Supply Chain Management Professionals (CSCMP) (2013) provides the following definition:

Supply Chain Management encompasses the planning and management of all activities involved in sourcing and procurement, conversion, and all logistics management activities. Importantly, it also includes coordination and collaboration with channel partners, which can be suppliers, intermediaries, third-party service providers, and customers. In essence, Supply Chain Management integrates supply and demand management within and across companies. Supply Chain Management is an integrating function with primary responsibility for linking major business functions and business processes within and across companies into a cohesive and high-performing business model.[...].

Accordingly, in a supply chain a multitude of companies undertake the activities required to satisfy end-customers' needs, and is best understood as a supply network (Croom, Romano, and Giannakis, 2000). The supply network encompasses all organizations involved in the different processes and activities that produce value in the form of products and services delivered to consumers (Christopher, 1992; Mentzer et al., 2001). A complex supply network can consist of manufacturers, component suppliers, distributors, retailers, consumers, third party logistics service providers, and other third-party service providers (e.g. banks, other 
financial providers, agents, brokers, and market research firms). Using CSCMP's (2013) definition of SCM, this paper's ambition is to contribute to more theorizing about SCM at the network level. Logistical service providers undertake activities associated with transport and warehousing such as inventory management, information related activities, including tracking and tracing, as well as the value-added activities of secondary assembly of products.

Which unit of analysis - the organisational entity for which researchers aim to describe and explain constructs, i.e. the level to which generalizations is appropriate (Rousseau, 1985) - is useful in SCM-research? This question is seldom raised, but according to Defee, Williams, and Randall (2010) dominant theories in SCM-research dictate the transaction or the firm as the unit of analysis. Since the main objective of SCM is the collaboration and concerted action involving a group of firms, it is not obvious that knowledge on transactional- and individual firms' characteristics contributes to new knowledge on SCM. Ideally, supply chain management research should hence seek to understand and explain collaboration and coordination between the organisations forming the supply network, or other important characteristics of the supply network. Not least because the supply network is widely referred to among practitioners and academics (Mentzer et al., 2001). In introductory SCM-classes, for example, it is common to mention how firms used to compete, but that nowadays competition occurs between (entire) supply networks.

Nevertheless, while for example relational norms of collaboration (MacNeil, 1980) are vital for collaboration among firms in the supply network, such norms have been investigated in dyads (e.g. Hammervoll, 2009), but not at the level of supply networks. Furthermore, Kembro and Näslund (2014) find, based on a literature review, that information sharing is studied from a focal company's perspective, and questions how such research enhances current knowledge 
on information sharing in supply networks. Indeed, a systematic literature review of 1048 papers published in the leading supply chain management journals during 2006-2012 reveals that SCM-research does not study supply network characteristics: the unit of analysis has been the business unit, dyad or firm (90\% of the papers), or the individual person, team or triad (10\% of the papers) (Kaufmann and Saw, 2014). In other words, the supply network is seldom the object of study. There is, accordingly, a need to expand the focus of study and to adopt the supply network as the unit of analysis (Carter and Easton, 2011; Autry and Griffis, 2008; Frankel et al., 2008; Harland, Lamming, and Cousins, 1999).

Accordingly, despite Oliver and Webber's (1982) early efforts, we still lack supply network level constructs and measures (Meixell and Gargeya, 2005; Wong and Wong, 2006; Chen and Paulraj, 2004). Therefor we have limited understanding on, for example, how supply networks compete and how they develop competitive advantage. Despite this need to expand the focus of study and to adopt the supply network as the unit of analysis, there is no guidance in the SCM-literature on how to accomplish this.

Marketing research has struggled with two measurement issues in particular - resolving the complexities associated with measuring latent constructs, and measuring constructs at multiple levels of analysis (Heide and John, 1995). With regard to the latter, it is recognised that higher-level units of analysis can be decomposed into lower level units, but also that the higher unit of analysis have properties in its own right. A buying center, for example, has characteristics that cannot be inferred from its employees' characteristics (Johnston and Bonoma, 1981). Similarly, a supply network has characteristics that cannot be understood by knowing the individual firms' characteristics. Furthermore, relevant constructs and research 
problems have been identified for various units of analysis (Wilke and Ritter, 2006), but the problems associated with expanding the unit of analysis has not been addressed.

The purpose of this paper is to fill some of this gap in the literature by discussing how to develop relevant SCM-constructs at the supply network level. Following this introduction, the unit of analysis problem in SCM-research is treated, and suggestions for further inquiry are presented.

Moving from one level of analysis to another raises multilevel issues (Klein, Dansereau and Hall, 1994; Rousseau, 1985). After developing constructs at the appropriate level of analysis, the next step is to build the model incorporating these constructs. Not all constructs in SCMresearch need to be at the level of supply networks, but target constructs should, in order to create new knowledge about supply networks. In this paper, attention is limited to appropriate construct development at the supply network level. A construct is an abstraction (of phenomena) that is not concrete and cannot be observed (Nunnally and Bernstein, 1994). In this paper, there is special emphasis on collaboration, a key, unobservable aspect of SCM, which cannot be researched without relevant constructs.

\section{SCM-RESEARCH AND THE UNIT OF ANALYSIS}

Despite recent initiatives to enhance theory building in SCM (e.g. Ketchen and Hult, 2011), level issues have barely been addressed, with the exception of some efforts to address constructs at the supply network level, like performance (Chibba and Hörte, 2003), innovation (Arlbjørn, de Haas, and Munksgaard, 2011), supply resilience (Blackhurst, Dunn, and Craighead, 2011) and strategy (Golicic and Sebastio, 2011). 
Borgatti and Li (2009) show that social network analysis (Burt, 1982) has the potential to contribute to development of SCM. Social aspects influence SCM decisions and supply network behaviour, but has received less attention than logistics as logistics has played a major role in SCM development (Frankel et al., 2008). For example, supply network density the degree of completeness of the ties between supply network members - is relevant for SCM-research (Vurro, Russo, and Perrini, 2007). Adopting constructs from other fields of research has its advantages as they operate at the appropriate unit of analysis and have undergone tests of validity and reliability in previous research.

Acknowledging the operation of social, psychological and economic forces among members in organizational units, it is important to understand the implications of construct definitions across levels (firm, dyad, chain and network) when expanding the unit of analysis (Klein et $a l .$, 1994). Compared to a construct at a lower level, such as the firm, constructs at the supply network level must be defined to include collective characteristics of the value creation system (Wilke and Ritter, 2006) with a common goal and other characteristics.

Consider this contemporary example in the SCM-literature: Tokman and Beitelspacher (2011) and Sanders and Wagner (2011) recommend further study of firms and firm-level constructs with clear ambition to advance the study of supply network constructs. At the outset, this is a sound approach because a good understanding at the 'micro-level' is required to understand supply network collaboration. It is useful to study different units of analysis for gaining a comprehensive understanding of a phenomenon (Wilke and Ritter, 2006). However, expanding the unit of analysis from firms to supply networks might require new constructs because the meaning of constructs can change across levels. 
What are, for example, the implications for the supply network creativity if each firm is creative? Drazin, Glynn and Kazanjian (1999) found creativity to result from both individual activities and dynamic group processes. Like in the world of football, assembling a team consisting of the best players (as measured at the individual level) is no guarantee that it will be the best performing team. Hence, even if each firm in a supply network is creative, the supply network does not have to be creative at all. For the researcher this means that knowledge on individual firms has little value if the ambition is to develop knowledge on the supply network.

\section{METHODS FOR UNIT OF ANALYSIS EXPANSION}

It is not clear how constructs at the firm level can contribute to the development of SCMknowledge. This depends on the affinities between supply network- and individual firm characteristics. There is no known toolbox containing all possible methods for unit of analysis expansion, but previous research has in part dealt with related issues. In principle there are three approaches for developing appropriate constructs for the expanded unit of analysis; 1) Use constructs that are similar to constructs operating at lower levels of analysis; 2) Aggregate constructs from lower levels of analysis; or 3) Develop new constructs. During this process, the researcher needs in particular to understand how supply networks constructs entail different variability assumptions with regard to the individual firms in the network.

Similar constructs - Constructs can be similar to constructs at lower levels of analysis and operate similarly across different units of analysis (Kozlowski and Klein, 2000; Rousseau, 1985). Similar constructs have the same conceptual definition, except that they concern different units of analysis. Due to social processes, constructs differ across levels and develop differently, but their effects on other constructs can be sufficiently similar across levels (Chen 
et al. 2005). There are no known examples of making this assumption in SCM-research, but the creativity literature uses similar constructs at the individual and the group level (Drazin, Glynn and Kazanjian, 1999).

Aggregate constructs - An aggregate construct is a construct that is defined as the sum or the consensus (dispersion) among the elements of a lower level of analysis. In business-tobusiness marketing research, data on individual characteristics are aggregated to describe organisational- or dyad-characteristics (Heide and John, 1995), such as the joint utility (Bagozzi, 1978). Such aggregation involves making strict assumptions about the relationships between constructs at different levels of analysis, and researchers are advised to carefully justify their approach (Heide and John, 1995).

There are also practical reasons for aggregate constructs, as when there is a lack of data at the higher level (Roberts, Hulin and Rosseau, 1978). Constructs must be defined such that when it comes to empirical work, data on a lower level of analysis are used to measure a variable at a higher level to compute the sum, mean and/or the variance (Chan, 1998 ${ }^{1}$ ).

Aggregation is commonly used in SCM-research for observable characteristics, like for example demand variability at different units of analysis (Reichhart and Holweg, 2007), but has not been applied to constructs on collaboration at the network level. Whenever it is unrealistic to access data at the supply network level, an aggregate constructs is one option worth considering in SCM-research.

\footnotetext{
${ }^{1}$ Chan (1998) also proposed an additional ideal type of aggregation logics - the process model - that is somewhat in accordance with the similar constructs method.
} 
New constructs - Using similar or aggregate constructs might not be good enough when the unit of analysis is expanded to a group of firms. This applies in particular for social phenomena, such as the behaviour of a supply network because the supply network's behaviour is greater than the sum of the firms' behaviour (Rousseau, 1985; Wilke and Ritter, 2006). Aggregation could not be used, for example, to model social interaction and group influence.

In business-to-business marketing research it is also recognised that aggregation involves making strict assumptions about the relationships between constructs at different levels of analysis, and that developing new constructs at the new level of analysis might be a better alternative (Heide and John, 1995). Such new constructs can be measured directly (without aggregation), and Heide and John refer to such measures as 'global'.

Aggregation assumes that construct definitions are based on group member characteristics, and that when it comes to measurement, data from each group member is included with equal weight. Whenever there are collective characteristics that need to be taken into account (e.g. when some group members are more dominant than others, or members vary in how (and how much) they interact with other members), new constructs that reflect such collective properties are needed.

In addition to identifying the organisational entity for which constructs belong to, the unit of analysis assumes variability at the lower unit of analysis (Dansereau, Alutto, and Yammarino, 1984). In an organisational behaviour perspective, there are three ideal types: (1) homogeneity within a higher unit of analysis, (2) independence from a higher unit of analysis, and (3) heterogeneity within a higher unit of analysis (Klein et al., 1994). In the football example, a 
player might for instance make a huge difference in one team, but not in another (players are heterogeneous). If players are independent, their performance is unaffected by their teammembership. Finally, if players are homogeneous, team performance is fully determined by team characteristics (which are unaffected by individual team members, beyond individual' players' contribution to aggregate characteristics), such as: the number of players, or their average age.

While Klein et al. (1994) discuss organisational entities at low levels (groups of individuals), they claim that their arguments are generic and apply to any organisational unit. Similar to a group of individuals, a supply network is a group of firms engaged in a common purpose (Borys and Jemison, 1989; Van de Ven et al., 1974; Van de Ven, 1976). Accordingly, a supply network construct treats the supply network's member firms as homogeneous, independent or heterogeneous.

Variability assumptions influence the nature of constructs as well as how constructs are related to other constructs. For a construct on collaboration in supply networks, firm homogeneity allows testing of differences between supply networks, and firm independence allows testing of differences between firms. Heterogeneity allows testing of differences between firms within supply networks, as illustrated in Table 1.

Please insert Table 1 about here 
Homogeneity - if firms are 'sufficiently similar', the supply network can be meaningfully described as a whole. In practise, this translates to that constructs describe supply network characteristics that are invariant across the supply network member firms. Dissimilar firms are sufficiently similar (homogeneous), as long as their differences do not affect the constructs of interest. Firms in supply networks (manufacturing firms, $\left(1^{\text {st }}, 2^{\text {nd }}, 3^{\text {rd }}\right.$, tier-) suppliers, customer firms, wholesalers, retailers, etc.) obviously are different, but this does not mean that they must be assumed to be independent or heterogeneous in relation to a specific construct. For example, supply network density - the degree of completeness of the ties between supply network members (Vurro et al., 2009) - does not require information about the firms.

Constructs can also operate at different levels. For example, an individual can be more or less creative, as can be an organisational unit (Drazin et al., 1999). If firms in a supply network are homogenous with regard to creativity, one construct of supply network creativity suffices for assessing the supply network's creativity. When properly operationalized and incorporated in a model, researchers are then able to study and to compare supply networks.

Independence - if firms are not sufficiently similar, the construct does not describe the supply network characteristic. The independence assumption means that assessing one firm gives no information on the supply network. This means that in un-integrated supply networks the independence assumption is more likely to hold (for behavioural constructs) than in managed supply networks (Mentzer et al., 2001; Min, Kim and Chen, 2008). If, for example, firms in a supply network were independent with regard to creativity, knowing one firm's creativity would not be useful for assessing the supply network's creativity. Again, dissimilar firms are sufficiently similar (homogeneous), as long as their differences do not affect the constructs of interest. The independence assumption allows research to study between-firm 
variability, but supply networks cannot be studied (not even as the context). This assumption should therefore be avoided for key constructs in SCM-research whenever the purpose is to develop knowledge on supply networks.

The independence assumption dictates that the firm is the appropriate unit of analysis (and that the construct is useless for gaining knowledge on supply networks), and the firm is a popular unit of analysis in contemporary SCM-research. This is reflected in, for example, Sanders and Wagner's (2011) assessment of contemporary SCM challenges; investigating the bottom line financial impact of SCM, and how firms should design their global supply networks.

Heterogeneity - if firms are not sufficiently similar but vary with regard to an attribute as a function of the supply network's average for this attribute, the construct addresses firm characteristics in the supply network context. The unit of analysis is the (context dependent) firm.

Considering sub-sets of supply networks, like for example groups of suppliers, customers or retailers, the heterogeneity assumption might allude to formal ranking procedures e.g. in terms of logistical ABC-analysis where effort towards supply network members are differentiated according to some criteria (i.e. sales or profits). There are few examples of constructs based on the heterogeneity assumption in SCM-research, but one example is Vurro et al.'s (2009) 'Centrality of the focal organisation' construct - the extent to which an organisation occupies a central position in the supply network. 
Ellinger et al. (2011) measure firm performance for SCM leader firms and compare the results with industry average. It is not unthinkable that a firm with a given level of SCM competency might perform well in one supply network, but not in another. If this is the case, the SCM competency construct can be studied as based on the heterogeneity assumption. Research attention should hence be to assess within supply network variability (differences between firms), and collection of relative firm scores (as opposed to absolute scores) within a supply network.

Klein et al.'s (1994) variability assumptions have been criticised for exaggerating group influence on individuals (the homogeneity assumption), and for ignoring group influence (the independence assumption) (George and James, 1994). However, the three variability assumptions must be treated as ideal types. The homogeneity assumption means that firms are sufficiently in general agreement on some supply network characteristic can be described as a whole. It does not assume that firm behaviour is entirely determined by characteristics of the supply network. Similarly, the independence assumption does not mean that firms are unaffected by belonging to a supply network.

To illustrate the differences between the various firm variability assumptions, consider how one collaborative aspect in supply networks, creativity, can be studied. If firms are homogeneous, constructs describing the supply network creativity (as a network characteristic), such as for example information exchange, can be related to outcomes of creativity, such as cost reductions, improved processes or increased revenues in the supply network. If firms are independent, firm creativity is of no interest for the study of supply networks unless this construct is incorporated in a multilevel model and related to creativity at the supply network level. Finally, constructs assuming heterogeneous firms, as for example 
centrality of the firm in creative supply network processes can be related to constructs at the firm level, such as the firm's commitment to creating value. Unless such constructs are incorporated in relevant multilevel models, they are not useful to the study of supply network creativeness.

In a similar way, when expanding the unit of analysis from the supply network to the industry (a group of supply networks), different assumptions regarding supply network variability within industries are made (as illustrated in Table 1). Jalalvand et al. (2011), for example, assume heterogeneous supply networks in their study of seven supply networks in the Iran chicken (broiler) industry. Jalalvand et al. (2011) describe and rank these supply networks with regard to performance attributes, thereby increasing our knowledge on SCM.

There is a lack of longitudinal research in SCM, but considering the different assumptions of variability with regard to the time-dimension (Klein et al., 1994) is an interesting point of departure for initiating such research. First, supply networks can be assumed to be homogeneous over time, which means that supply-network characteristics are stable over time. Second, supply networks can be assumed independent. This means that supply-network characteristics are independent of the supply network - for example because of situational factors. Thirdly, heterogeneous supply networks means that observations of supply-network characteristics can be predicted evolving about the mean for each supply network. For example, do periods with lower level of creative activity follow periods of high creativity activity?

\section{PROPOSITIONS}


SCM-research seldom addresses characteristics of supply networks. The lack of relevant constructs is one explanation for this, but another explanation is that it is challenging and resource demanding to research supply network characteristics (Provan et al., 2007; Kaufmann and Saw, 2014). Collecting primary data on networks usually requires more workintensive methods than common data collection methods in SCM-research, such as surveys and interviews with many key informants. Still, researchers can rely more on secondary data sources and conduct historical case analysis based on archival records and documents, corporate communications, as well as media and press reports. Eventually, combining secondary data with primary data is an opportunity (Rabinovich and Cheon, 2011).

In order to increase the number of relevant constructs for the study of SCM, researchers need to fully recognise that SCM concerns a group of firms, and that the appropriate unit of analysis for key constructs of study is the supply network. Hence, conducting research that explains constructs at the firm- or dyadic level of analysis will not directly advance SCM knowledge. This position is not compatible with currents approaches to SCM considering for example how a firm should manage its supply network (see e.g. Sanders and Wagner, 2011). SCM is a collective enterprise, and their characteristics and collaborative processes depend on these firms collectively.

Such reorientation towards a new and expanded unit of analysis is a huge undertaking, as it also entails the development of new and relevant constructs at the network level. In a field of study embracing lower units of analysis, such as transactions and firms, a nagging question is to what extent existing knowledge on constructs at a lower level of analysis is valuable for 'new' constructs at the network level? As has been argued in this paper SCM-research will benefit from developing new constructs directly at the level of supply networks since on many 
occasions (and particular with regard to behavioural constructs) this is the only way to capture the collective properties of such networks.

In contrast, gradually 'enlarging' the unit of analysis with the aim of eventually explaining supply network phenomenon is problematic because the meaning of behavioural constructs differ across organisational entities (Klein et al., 1994; Chen and Paulraj, 2004). The critical task is to consciously define constructs. For example, Tokman and Beitelspacher (2011) suggest studying firm creativeness in order to advance our knowledge on collaboration in supply networks. Since firms differ to the extent to which they are creative, this research has the potential to increase our understanding of supply networks as a context in which there is creation of value. For example, how do firms' confidence in own capabilities lead to more active participation in supply network decision-making? Still, this approach assumes heterogeneous firms, and does not allow comparisons between supply networks. Most importantly, such research will not be able to explain why some supply networks are more innovative than other supply networks. Each firm's degree of creativeness cannot be aggregated to reflect the supply network's creativeness because it is not possible to relate 'variability between individual firms' to constructs that describe 'between supply networks variability'. In order to study the supply network's creativeness requires creativeness to be conceptualised at the level of supply network.

The following example illustrates how one construct, innovation, is conceptualised at different levels of analysis. In their review of innovation constructs at different levels of analysis, Gupta et al. (2007) identify various creativity- and innovation constructs (as illustrated in Table 2). Innovation is the production or emergence of a new idea (Gupta et al., 2007: 886). A creative individual has certain personality and intellectual traits, and given a 
measure of free rein, spends significant amounts of time engaged in the creative process (Findley and Lumsden, 1988).

Considering the outputs of creativity, Taggar (2002) finds that group creativity cannot be aggregated from individual creativity, but emerges synergistically when members interact in certain ways. Hence, while creativity at the individual level is a function of personal characteristics, group interactions and group processes play an important role in shaping group creativity. Creativity is the first step in innovation, but at the firm level, various aspects of innovation (and not creativity) has attracted researchers' attention: technological innovation, new product development and organisational innovation.

Please insert Table 2 here

As noted by researchers (e.g. Provan et al., 2007; Kaufmann and Saw, 2014), it is difficult and resource demanding to collect data on entities consisting of several firms, such as supply networks, because data needs to be collected from each firm. This statement is true of course, whenever one needs to learn about all the firms in the network. At the same time, this statement is not valid when each firm in the network does not have to provide data. Global measures can be used in such instances (Heide and John, 1995). Global measures directly assess the characteristics of the unit of analysis. The most common approach for collecting data on global measures is the use of key-informants, but secondary data (from contracts and documents) is also an option. The use of key-informants is potentially effective, but is also 
associated with some controversy. According to Heide and John (1995) the quality of data from key-informants have only been scientifically evaluated in one single study, and they conclude that the critical issue in using key-informants is to make sure that the construct's theoretical content fits the unit of analysis (and corresponds to the global measure used). In other words, the unit of observation (unit of measurement) need not correspond to the unit of analysis, as long as the measure is global. The new construct need to fit the higher unit of analysis (and the same applies to the measure used) when developing new constructs.

Considering, for example innovation at the supply network level (see Table 2), in terms of RFID-implementation. This construct need not be measured in the intuitional way by surveying all supply network members - but can be measured by collecting data on global measures from key-informants.

Still, the belief that there are severe methodological challenges associated with collecting data on supply networks is firmly rooted in research communities, and the best way to fight it is by demonstrating that it does not need to be so. One strategy should be to increase consciousness on the unit of observation in research.

Wilke and Ritter (2006) note that the unit of observation does not need to coincide with the unit of analysis. It is, for example, possible to collect data on supply networks from lower levels. Still, such approach is not common. One reason for this is the fear that the perceptions of an individual, for example, is not good enough for measuring a supply network characteristic, and that multiple informants are needed. However, as illustrated in Table 2 it is obvious that supply network characteristics, such as innovation, can be measured without collecting data from each individual in the network. Considering for example innovation at 
the supply network level in terms of RFID-implementation, one interview with one industry expert would normally suffice for getting good data. Hopefully a more conscious approach to construct development will encourage more researchers to collect data on supply network characteristics in less resource demanding ways than has been the traditional approach to the study of networks.

Parting from the premise that an important ambition of SCM-research is to explain and develop knowledge about some supply network characteristics, one way to enrich our conceptual inventory is hence to develop new constructs at the level of supply networks that assumes firm homogeneity. For example, following Stock's (1997) recommendation to borrow from other fields, SCM can adopt collaboration constructs from the literature on interorganizational relationships (e.g. Borys and Jemison (1989) define collaboration as the process whereby the capabilities of firms are combined such that the competitive advantage of one or more firms is improved). Despite firms in supply networks being different, firms are homogeneous when constructs describe collective properties. Bititchi et al. (2004) study value configurations in supply networks much similar to Borys and Jemison's (1989) ideas, but there is room for further efforts.

Expanding the unit of analysis from firms to supply networks raises two immediate issues: How can the supply network be defined and identified for conducting relevant research, and what can be done to comply with the homogeneity assumption?

\section{The supply network as the unit of analysis in SCM-research}

Researching collaboration in a network entails mapping and assessing the totality of interactions between firms in the network in order to derive its collective characteristics. This 
can be a resource demanding activity, but in addition, it is a challenge to define and to identify the relevant members in the network because the network never ends (Håkansson and Snehota, 1995). There is hence, a challenge to identify the networks boundaries.

A supply network can be highly complex because in addition to the main players, many firms make small contributions to the functioning of the network. In order to identify active members, it is useful to distinguish those firms that are engaged in managed linkages (Lambert et al., 1998) from other firms. Firms that are engaged in linkages that are not actively managed are not under any influence or pressure for supply network integration. Accordingly, these firms are not affected by SCM (Min et al., 2008; Mentzer et al., 2001). For the purpose of SCM-research, then, the supply network should therefore be limited to those firms that are engaged in managed supply network linkages. The managed supply network is a meaningful inter-organisational and social entity characterised by, for example, purpose, structure and collaborative value-creation processes (Van de Ven et al., 1974; Van de Ven, 1976; Borys and Jemison, 1989). This is not to say that firms only strive for mutually beneficial outcomes (Mudambi and Helper, 1998). The following proposition summarises the arguments above:

\section{P1 In SCM-research where the purpose is to explain differences between supply networks, the target construct must operate at the managed supply network level of analysis.}

The research model can be multilevel, which means that constructs (except for the target construct) can operate at lower levels of analysis. 


\section{The homogeneity assumption}

When expanding the unit of analysis, the construct of interest must assume homogeneity at lower levels of analysis. In principle, expanding the unit of analysis to the supply network obeys to scientific criteria for construct development as long as the construct captures supply network characteristics. This means that motivational issues and potentially important results of individual firms' actions often need to be side-stepped in research on collaboration in firm networks (e.g. Vurro et al., 2009), simply because they are not helpful in reflecting the network's characteristics. However, researchers should carefully define constructs, especially when the new construct at the outset is similar to constructs at lower levels of analysis but operates differently across different units of analysis. At least this would stagger unfair criticism regarding the neglect of individual firms' interests, knowledge, preferences and expectations.

SCM affects firms in managed linkages in a supply network, and this has implications for constructs' variability assumptions. For example, familiarity with the other firms in the supply network affects how collaboration develops (Gulati, 1995; Håkansson and Snehota, 1995). The same way as individuals actively form groups, create group processes, and create group characteristics (Bowers, 1973), firms in supply networks affect how the network is formed, its processes and characteristics (Håkansson and Snehota, 1995). For example, firms similar on some attributes are attracted to and selected into a supply network as they share similar production philosophies and ideologies, or socialize and develop common experience and norms on how to interact. There has, for example, been observed how a strong desire to produce healthy food, or to produce wine made according to local traditions, represents the raison d'être of membership in some food supply networks (Hammervoll and Toften, 2014). 
The homogeneity assumption is therefore positively associated with inter-organisational processes among supply network member firms that promote the development of relational norms of collaboration (MacNeil, 1980). Such norms have been investigated in dyads (e.g. Wang and Wei, 2007), but not at the level of supply networks. In the absence of such relational norms, the supply network lacks a social identity, and collaboration constructs are more likely to assume independence among firms, rather than homogeneity.

For cooperation constructs, the common approach is to collect primary data and rely on perceptive measures (Hammervoll, 2009). The rule of thumb when studying relational norms in firm networks is to assume that $2-3$ years of familiarity are required to establish relational norms (Narus and Anderson, 1986). In sum, this discussion suggests the following propositions:

P2 If the construct of interest does not assume homogeneous firms, a new construct need to be defined at the supply network level when expanding the unit of analysis to the managed supply network.

P3 Selection-, socialisation-, and other integrative processes in supply networks increase firm homogeneity for SCM-constructs.

\section{CONCLUSIONS AND IMPLICATIONS}

The schematic representation on alternative units of analysis and research purposes in Table 1 points to new research opportunities. In order to retain academic credibility beyond the current hype, SCM-researcher should study the supply network characteristics and differences between supply networks. The unit of analysis is a fundamental research quality issue, 
particularly for judging the relevance of SCM-research, and a preoccupation with extending the unit of analysis to supply networks is called for.

There is three possible approaches. First, research might adopt the supply network as the unit of analysis, assuming its supply network members to be homogeneous with regard to the theoretical constructs of interest. This means that constructs are descriptive of the supply network's properties. Few studies have addressed SCM-constructs at the level of supply networks. Recognising that prospects are poor to advance SCM-knowledge with firm level collaboration constructs, new constructs are called for. In particular, insights from theory on inter-organizational relationships, clusters and social networks should be adapted to the study of supply network. Further research can for example, provide guidance as to when different forms of SCM are most effective in supply networks.

The second option is to study constructs that assume heterogeneous firms within supply networks. This means that the firm is the unit of analysis, and the supply network is the context. Assuming heterogeneous firms can generate new insights for SCM. For example, firms strive to achieve some specific benefits from a position in a knowledge-sharing network. How will this impact knowledge sharing among firms in the supply network? Such questions are usually not raised, much less resolved, in the SCM-literature.

Third, considering industries as a group of heterogeneous supply networks, supply networks can be studied in the specific industry context.

Three propositions apt at guiding further research are suggested. While two of them (P1 and P2) are meant to guide research efforts with regard to defining constructs at the level of supply 
networks, the third (P3) can stimulate empirical testing of the homogeneity assumption. Homogeneity is expected to result from supply network integration processes, such as selection- and socialisation. Moving from the conceptual to the empirical level, homogeneity can be assessed by measuring aspects of collaboration as perceived at the firm level and by comparing the obtained scores across firms in a supply network. Low variability observed between firm perceptions indicates that firms can be treated as homogeneous.

One reason why most SCM-research addresses other units of analysis than the supply network is the long-lived belief that it is (too) difficult to research supply networks. While this is a valid argument for aggregate constructs, it does not hold for new constructs concerning supply network characteristics. In order to avoid the continued violation of scientific principles of relevance and parsimony it is time for developing new constructs in SCM-research for the study of supply network characteristics. The alternative is to change the definition of supply networks and SCM. In practise, one opportunity for research is to develop new constructs or adopt constructs from related fields taking firm networks as the unit of analysis, develop global measures, and collect data on supply networks from key-informants, such as industry experts. 


\section{REFERENCES}

Ahuja, G., and Katila, R. (2001), "Technological Acquisitions and the Innovation Performance of Acquiring Firms: A Longitudinal Study", Strategic Management Journal, Vol. 22, pp. 197-220.

Arlbjørn, J.S., de Haas, H., and Munksgaard, K.B. (2011), "Exploring Supply Chain Innovation”, Logistics Research, Vol. 3 No. 1, downloaded 06 January 2011.

Armour, H.O., and Teece, D.J. (1980), "Vertical Integration and Technological Innovation”, Review of Economics and Statistics, Vol. 62, pp. 470-74.

Autry, C.W., and Griffis, S.E. (2008), "Supply Chain Capital: the Impact of Structural and Relational Linkages on Firm Execution and Innovation", Journal of Business Logistics, Vol. 29 No. 1, pp. 157-73.

Bagozzi, R.P, (1978), “Marketing as Exchange”, American Behavioral Scientist, Vol. 21 No. 1, pp. 535-56.

Bititchi, U.S., Martinez, V., Albores, P., and Parung, J. (2004), "Creating and Managing Value in Collaborative Networks", International Journal of Physical Distribution and Logistics Management, Vol. 34 Nos. 3/4, pp. 251-68.

Blackhurst, J., Dunn, K.S., and Craighead, C.W. (2011), “An Empirically Derived Framework of Global Supply Resiliency”, Journal of Business Logistics, Vol. 32 No. 4, pp. 374-91.

Boden, M. (2003), The Creative Mind: Myths and Mechanisms, Routledge: London.

Borgatti, S., and Li, X. (2009), "On Social Network Analysis in a Supply Chain Context", Journal of Supply Chain Management, Vol. 45 No. 2, pp. 5-22.

Borys, B. and Jemison, D.B. (1989), "Hybrid Arrangements as Strategic Alliances: Theoretical Issues in Organizational Combinations", Academy of Management Review, Vol. 14, pp. 234-49. 
Bowers, K.S. (1973), “Situationism in Psychology: an Analysis and Critique”, Psychological Review, Vol. 30, pp. 307-36.

Burt, R. (1982), Toward a Structural Theory of Action: Network Models of Social Structure, Perception, and Action, Academic Press, New York, NY.

Carter, C.R., and Easton, P.L. (2011), “Sustainable Supply Chain Management: Evolution and Future Directions", International Journal of Physical Distribution and Logistics Management, Vol. 41 No. 1, pp. 46-62.

Chan, G., Bliese, P.D. and Mathieu, J.E. (2005), "Conceptual Framework and Statistical Procedures for Delineating and Testing Multilevel Theories of Homology”, Organizational Research Methods, Vol. 8 No. 4, pp. 375-409.

Chen, D. (1998), "Functional Relations among Constructs in the Same Content Domain at Different Levels of Analysis: A Typology of Composition Models", Journal of Applied Psychology, Vol. 83 No. 2, pp. 234-46.

Chen, I.J. and Paulraj, A. (2004), "Towards a Theory of Supply Chain Management: the Constructs and Measurements", Journal of Operations Management, Vol. 22, pp. 119-50.

Chibba, A. and Hörte, S.Å. (2003), Supply Chain Performance - a Meta Analysis, School of Business and Engineering, University of Halmstad, Halmstad, Sweden.

Christopher, M.L. (1992), Logistics and Supply Chain Management, Pitman Publishing, London.

Croom, S., Romano, P. and Giannakis, M. (2000), "Supply Chain Management: an Analytical Framework for Critical Literature Review”, European Journal of Purchasing and Supply Management, Vol. 6 No. 1, pp. 67-83.

CSCMP, (2013), "Supply Chain Management: Terms and Glossary." available at: http://cscmp.org/sites/default/files/user_uploads/resources/downloads/glossary-2013.pdf (accessed December 12, 2013). 
Dansereau, F., Alutto, J.A., and Yammarino, F.J. (1984), Theory Testing in Organisational Behaviour: the Variant Approach, Prentice Hall, Englewood Cliffs, NJ.

Defee, C.C., Williams, B. and Randall, W.S. (2010), “An Inventory of Theory in Logistics and SCM-research", International Journal of Logistics Management, Vol. 21 No. 3, pp. 404-89.

Drazin, R., Glynn, M.A. and Kazanjian, R.K. (1999), "Multilevel Theorizing About Creativity in Organizations: A Sensemaking Perspective”, Academy of Management Review, Vol. 24 No. 2, pp. 286-307.

Ellinger, A.E., Natarajarathinam, M., Adams, F.G., Gray, B., Hofman, D., and O’Marah, K.O. (2011), "Supply Chain Management Competency and Firm Financial Success", Journal of Business Logistics, Vol. 32 No. 3, pp. 214-26.

Fawcett, S.E., Fawcett, A.M., Watson, B.J., and Mangan, G.M. (2012), "Peeking Inside the Black Box: Toward an Understanding of Supply Chain Collaboration Dynamics", Journal of Supply Chain Management, Vol. 48 No. 1, pp. 44-72.

Findlay, C.S., and Lumsden, C.J. (1988), “The Creative Mind: Toward an Evolutionary Theory of Discovery and Innovation”, Journal of Social and Biological Structures, Vol. 11, pp. 3-55.

Fleming, L., and Waguespack, D.M. (2007), "Brokerage, Boundary Spanning, and Leadership in Open Innovation Communities”, Organization Science, Vol. 18 No. 2, pp. 165-84.

Frankel, R., Bolumole, Y.A., Eltantawy, R.A., Paulraj, A., and Gundlach, G.T. (2008), “The Domain and Scope of SCM's Foundational Disciplines - Insights and Issues to Advance Research”, Journal of Business Logistics, Vol. 29 No. 1, pp. 1-30.

George, J.M., and James, L.R. (1994), "Level Issues in Theory Development”, Academy of Management Review, Vol. 19 No. 4, pp. 636-40. 
Golicic, S.L., and Sebastiao H.J. (2011), "Supply Chain Strategy in Nascent Markets: The Role of Supply Chain Development in the Commercialization Process", Journal of Business Logistics, Vol. 32 No. 3, pp. 254-73.

Gulati, R. (1995), “Does Familiarity Breed Trust? The Implications of Repeated Ties for Contractual Choice in Alliances", Academy of Management Journal, Vol. 38, pp. 85-112. Gupta, A.K., Tesluk, P.E., and Taylor, M.S. (2007), "Innovation at and Across Multiple Levels of Analysis", Organization Science, Vol. 18 No. 6, pp. 885-97.

Hammervoll, T. (2009), “Channel Cooperation: a Reflective Scale”, International Journal of Logistics Management, Vol. 20 No. 3, pp. 301-21.

Hammervoll, T., and Toften, K. (2014), "Niche Firms and Partnerships in International Food Supply Chains”, Journal of Food Products Marketing, Vol. 20 No. 1, pp. 36-54.

Harland, C.M., Lamming, R.C., and Cousins, P.D. (1999), "Developing the Concept of Supply Strategy", International Journal of Operations and Production Management, Vol. 19, pp. 650-73.

Heide, J. B., and John, G. (1995), "Measurement Issues in Research on Inter-Firm Relationships", in Business Marketing: An Interaction and Network Perspective, D.T. Wilson and K. Moller (Eds.), Boston, MA: PWS-Kent, pp. 531-54.

Hult, G.T.M.M., Ketchen, D.J., and Slater, S.F. (2004), “Information Processing, Knowledge Development, and Strategic Supply Chain Performance", Academy of Management Journal, Vol. 47, pp. 241-53.

Håkansson, H. and I. Snehota. (1995), Developing Relationships in Business Networks, Routledge, London.

Jalalvand, F., Teimoury, E., Makui, A. and Aryanezhad, M.B. (2011), “A Method to Compare Supply Chains of an Industry", Supply Chain Management: An International Journal, Vol. 16 No. 2, pp. 82-99. 
Johnston, W.J., and Bonoma, T.V., (1981), “The Buying Center: Structure and Interaction Patterns", Journal of Marketing, Vol. 45 (Summer), pp. 143-56.

Kaufmann, L., and Saw, A.A. (2014), "Using a Multiple-Informant Approach in SCM Research", International Journal of Physical Distribution and Logistics Management, Vol. 44 No. 6, pp. 511-27.

Kembro, J., and Näslund, D. (2014), "Information Sharing in Supply Chains, Myth or Reality? A Critical Analysis of Empirical Evidence", International Journal of Physical Distribution and Logistics Management, Vol. 44 No. 3, pp. 179-200

Ketchen, D.J. and Hult, G.T.M. (2011), "Building Theory about Supply Chain Management: some Tools from the Organizational Sciences", Supply Chain Management, Vol. 47 No. 2, pp. 12-18.

Klein, K.J., Dansereau, F., and Hall, R.J. (1994), "Levels Issues in Theory Development, Data Collection, and Analysis", Academy of Management Review, Vol. 19 No. 2, pp. 195-229.

Kozlowski, S.W.J. and Klein, K.J. (2000), “A Multilevel approach to Theory and Research in Organizations: Contextual, Temporal, and Emergent Processes", in Klein, K.J. and Kozlowski, S.W.J. (Eds.), Multilevel Theory, Research, and Methods in Organizations: Foundations, Extensions, and New Directions, Jossey-Bass, San Francisco, pp. 3-90.

Lambert, D.M., Cooper, M.C., and Pagh, J.D., (1998), "Supply Chain Management: Implementation Issues and Research Opportunities", International Journal of Logistics Management, Vol. 9 No. 2, pp. 1-19.

MacNeil, I.R. (1980), The New Social Contract. An Inquiry into Modern Contractual Relations, Yale University Press, New Haven, CT.

Mentzer, J.T., DeWitt, W., Keebler, J.S., Min, S., Niz, N.W., Smith, C.D., and Zacharia, Z.G. (2001), “Defining Supply Chain Management”, Journal of Business Logistics, Vol. 22 No. 2, pp. $1-25$. 
Meixell, M.J. and Gargeya, V.B. (2005), “Global Supply Chain Design: a Literature Review and Critique", Transportation Research, Part E: Logistics and Transportation Review, Vol. 41 No. 6, pp. 531-50.

Min, S., Kim, S.K., and Chen, H. (2008), "Developing Social Identity and Social Capital for Supply Chain Management”, Journal of Business Logistics, Vol. 29 No. 1, pp. 283-304.

Mudambi, R. and Helper, S. (1998), “The 'Close but Adversarial' Model of Supplier Relations in the U.S. Auto Industry", Strategic Management Journal, Vol. 19, pp. 775-92.

Nunnally, J.C. and Bernstein, I.H. (1994), Psychometric Theory ( $3^{\text {rd }}$ Ed.), McGraw Hill, New York.

Oliver, R.K. and Webber, M.D. (1982), "Supply-Chain Management: Logistics Catches up with Strategy", in Logistics: The Strategic Issues, Christopher, M. (Ed.), Chapman Hill, London, pp. 63-75.

O’Reilly, III, C.A., and Tushman, M.L. (2004), “The ambidextrous Organization”, Harvard Business Review, Vol. 82, pp. 74-82.

Perry-Smith, J.E. (2006), "Social yet Creative: The Role of Social Relationships in Facilitating Individual Creativity", Academy of Management Journal, Vol. 49, pp. 85-101.

Phillips, L.W. (1981), “Assessing Measurement Error in Key Informant Reports: A Methodological Note on Organizational Analysis in Marketing”, Journal of Marketing Research, Vol. 18, pp. 395-415.

Provan, K.G., Fish, A., and Sydow, J. (2007), "Interorganizational Networks at the Network Level: A Review of the Empirical Literature on Whole Networks", Journal of Management, Vol. 33 No. 3, pp. 479-516.

Puranam, P., Singh, H., and Zollo (2006), “Organizing for Innovation: Managing the Coordination-Autonomy Dilemma in Technology Acquisitions", Academy of Management Journal, Vol. 49, pp. 263-80. 
Rabinovich, E. and Cheon, S.H. (2011), "Expanding Horizons and Deepening Understanding via the Use of Secondary Data Sources”, Journal of Business Logistics, Vol. 32 No. 4, pp: 303-16.

Reichhart, A. and Holweg, M. (2007), "Creating the Customer-Responsive Supply Chain: a Reconciliation of Concepts", International Journal of Operation \& Production Management, Vol. 27 No. 11, pp. 1142-72.

Roberts, K.H., Hulin, C.L., and Rousseau, D.M. (1978), Developing an Interdisciplinary Science of Organizations, Jossey-Bass, San Francisco.

Rousseau, D.M. (1985), Issues of Level in Organizational Research: Multilevel and CrossLevel Perspectives, in Cummings, L.L. and Staw, B.M. (Eds.), Research in Organizational Behaviour, JAI Press, Greenwich, CT, Vol. 7, pp. 1-37.

Sanders, N.R., and Wagner, S.M. (2011), "Multidisciplinary and Multimethod Research for Addressing Contemporary Supply Chain Challenges", Journal of Business Logistics, Vol. 32 No. 4, pp. 317-23.

Stock, J.R. (1997), “Applying Theories from Other Disciplines to Logistics”, International Journal of Physical Distribution \& Logistics Management, Vol. 27 Nos. 9/10, pp. 515-39.

Taggar, S. (2002), "Individual Creativity and Group Ability to Utilize Individual Creative Resources: a Multilevel Model”, Academy of Management Journal, Vol. 45, No. 2, pp. $315-330$.

Taylor, A., and Greve, H.R. (2006), "Superman or the Fantastic Four? Knowledge Combination and Experience in Innovative Teams", Academy of Management Journal, Vol. 49, pp. 723-40.

Teece, D.J. (1986), "Profiting from Technological Innovation”, Research Policy, Vol. 15 No. 6, pp. 285-305. 
Tokman, M. and Beitelspacher, L.S. (2011), "Supply Chain Networks and Service-Dominant Logic: Suggestions for Future Research", International Journal of Physical Distribution and Logistics Management, Vol. 41 No. 7, pp. 717-26.

Van de Ven, A.H., Emmet, D.C., and Koenig, R.Jr. (1974), "Frameworks for Interorganizational Analysis", Organization and Administrative Science, Vol. 5 No. 1, pp. 113-29.

Van de Ven, A.H. (1976), "On the Nature, Formation and Maintenance of Relations Among Organizations", Academy of Management Review, Vol. 1, pp. 24-36.

Vurro, C., Russo, A., and Perrini, F. (2009), "Shaping Sustainable Value Chains: Network Determinants of Supply Chain Governance Models", Journal of Business Ethics, Vol. 90, pp. 607-21.

Wang, E.T.G., and Wei, H.-L. (2007), "Interorganizational Governance Value Creation: Coordinating for Information Visibility and Flexibility in Supply Chains", Decision Sciences, Vol. 338 No. 4, pp. 647-74.

Wilke, R. and Ritter, T. (2006), "Levels of Analysis in Business-to-Business Marketing", Journal of Business-to-Business Marketing, Vol. 13 No. 3, pp. 39-64.

Wong, W.P. and Wong, K.Y. (2006), "A Review on Benchmarking of Supply Chain Performance Measures", Benchmarking: An International Journal, Vol. 15 No. 1, pp. 2551. 
Table 1. Constructs: variability assumptions, unit of analysis and explanatory purpose.

\begin{tabular}{|c|c|c|c|}
\hline Level & $\begin{array}{l}\text { Variability } \\
\text { assumptions }\end{array}$ & $\begin{array}{l}\text { Unit of } \\
\text { analysis }\end{array}$ & Explanatory purpose \\
\hline \multirow{3}{*}{$\begin{array}{l}\text { Supply } \\
\text { network }\end{array}$} & Homogeneous firms & $\begin{array}{l}\text { Supply } \\
\text { network }\end{array}$ & $\begin{array}{l}\text { Differences between } \\
\text { supply networks }\end{array}$ \\
\hline & Independent firms & Firm & $\begin{array}{l}\text { Differences between firms } \\
\text { (irrespective of supply } \\
\text { network membership) }\end{array}$ \\
\hline & $\begin{array}{l}\text { Heterogeneous } \\
\text { firms }\end{array}$ & Firm & $\begin{array}{l}\text { Differences between firms } \\
\text { in a specific supply } \\
\text { network }\end{array}$ \\
\hline \multirow{3}{*}{ Industry } & $\begin{array}{l}\text { Homogeneous } \\
\text { supply networks }\end{array}$ & Industry & $\begin{array}{l}\text { Differences between } \\
\text { industries }\end{array}$ \\
\hline & $\begin{array}{l}\text { Independent supply } \\
\text { networks }\end{array}$ & $\begin{array}{l}\text { Supply } \\
\text { network }\end{array}$ & $\begin{array}{l}\text { Differences between } \\
\text { supply networks } \\
\text { (irrespective of industry } \\
\text { membership) }\end{array}$ \\
\hline & $\begin{array}{l}\text { Heterogeneous } \\
\text { supply networks }\end{array}$ & $\begin{array}{l}\text { Supply } \\
\text { network }\end{array}$ & $\begin{array}{l}\text { Differences between } \\
\text { supply networks in a } \\
\text { specific industry }\end{array}$ \\
\hline
\end{tabular}


Table 2. Innovation constructs at different levels of analysis

\begin{tabular}{|c|c|c|}
\hline Level & Construct & Example \\
\hline \multirow{2}{*}{ Individual } & \multirow{2}{*}{ Creativity } & $\begin{array}{l}\text { Individual creativity as an outcome of underlying } \\
\text { personality traits and temporary psychological states } \\
\text { (Boden, 2003). }\end{array}$ \\
\hline & & $\begin{array}{l}\text { Individual creativity within organisations. The impact } \\
\text { of network ties on the creative contributions of } \\
\text { scientists (Perry-Smith, 2006). }\end{array}$ \\
\hline Group & Creativity & $\begin{array}{l}\text { Factors that curb or foster group creativity: group } \\
\text { composition and group processes (Taylor and Greve, } \\
\text { 2006) }\end{array}$ \\
\hline \multirow{3}{*}{ Organisation } & $\begin{array}{c}\text { Technological } \\
\text { innovation }\end{array}$ & $\begin{array}{c}\text { Factors that affect the extent to which an organisation is } \\
\text { successful at technological innovation (Armour and } \\
\text { Teece, 1980), and factors that affect whether an } \\
\text { organisation is able to appropriate the value from } \\
\text { technological innovation (Teece, 1986). }\end{array}$ \\
\hline & $\begin{array}{c}\text { New product } \\
\text { (new } \\
\text { business-) } \\
\text { development } \\
\text { within the } \\
\text { established } \\
\text { organisation } \\
\end{array}$ & $\begin{array}{l}\text { The tension between exploration and exploitation } \\
\text { (ambidexterity) (O'Reilly and Tushman, 2004). }\end{array}$ \\
\hline & $\begin{array}{c}\text { Organisational } \\
\text { innovation }\end{array}$ & $\begin{array}{l}\text { The impact of being acquired on product innovation } \\
\text { (Puranam et al., 2006). How acquisitions affect } \\
\text { postacquisition innovation by the acquiring firm (Ahuja } \\
\text { and Katila, 2001). }\end{array}$ \\
\hline Industry & Innovations & $\begin{array}{l}\text { Interplay between the structure and dynamics of } \\
\text { industries and the emergence and diffusion of } \\
\text { innovations (Fleming and Waguespack, 2007). }\end{array}$ \\
\hline
\end{tabular}




\section{IMPLICATIONS FOR BUSINESS MARKETING PRACTICE}

SCM-research is complex in the sense that it investigates various aspect of SCM, and builds on a variety of different theories. Popular theories apply to transactions, or firms, but ideally, SCM-research should examine theories that address the characteristics of supply networks. All though SCM-academics agree that the supply network is too seldom the unit of analysis, and also that we lack relevant constructs and measures describing supply network characteristics, there is no guidance in the literature on how to expand the unit of analysis from firms to supply networks.

In order to address how the unit of analysis in SCM-research can be expanded from firms to supply networks, this paper reviews different methods for unit of analysis expansion: 1) use constructs that are similar to constructs operating at lower levels of analysis, 2) aggregate constructs from lower levels of analysis, and 3) develop new constructs. Also, constructs vary in their variability assumptions, unit of analysis and explanatory purpose. When the purpose is to explain some phenomenon at the supply network level, for example, firms need to be considered homogeneous, for the target construct. For constructs that assume independent firms, only differences between firm (irrespective of which supply network they belong to) can be explained. Similarly, for construct that assume heterogeneous firms, only differences between firms in a specific supply network can be explained.

The conclusion is that constructs related to cooperation in supply networks should be developed or adopted from other research fields dealing with firm networks, because such constructs cannot be aggregated from, or adopted from, lower levels of analysis. In particular, one opportunity for future research is to challenge the long-lived belief that firm networks are difficult to research: By developing new constructs, global measures on supply network 
characteristics can be used to collect data from key-informants. This data-collection method is appropriate and cost-effective, but assumes that the constructs are consciously defined.

Three propositions apt at guiding further research are suggested. This paper contributes to the debate on how to develop more relevant SCM-research. The insights can encourage business managers to consider in more detail, and with more scepticism, current research findings on supply networks. If practitioners take an interest in discussions on the unit of analysis and on the assumptions (be they implicit or explicit) on which collaborative constructs in supply networks are based, the quality of research has the potential to significantly improve. SCMresearch is still young, and the door is wide open for researchers and practitioners to contribute to more SCM-knowledge. 